\title{
Kaolin Consumption Affects Serum Electrolytes, Glucose and Amylase Levels of Pregnant Women
}

\author{
Thomas 0. Zeigbo1, Peter A. Akah ${ }^{1,2^{*}}$, Martha N. Ofokansi ${ }^{2}$ \\ ${ }^{1}$ Department of Pharmacology and Toxicology, Nnamdi Azikiwe University, Awka, Nigeria \\ ${ }^{2}$ Department of Pharmacology and Toxicology, University of Nigeria, Nsukka, Nigeria \\ Email: * peter.akah@unn.edu.ng
}

How to cite this paper: Zeigbo, T.O., Akah, P.A. and Ofokansi, M.N. (2020) Kaolin Consumption Affects Serum Electrolytes, Glucose and Amylase Levels of Pregnant Women. Journal of Biosciences and Medicines, 8, 160-168.

https://doi.org/10.4236/jbm.2020.86015

Received: April 17, 2020

Accepted: June 13, 2020

Published: June 16, 2020

Copyright $\odot 2020$ by author(s) and Scientific Research Publishing Inc. This work is licensed under the Creative Commons Attribution International License (CC BY 4.0).

http://creativecommons.org/licenses/by/4.0/

\begin{abstract}
Background: Geophagy is the consumption of earth materials which occurs across several cultures. For several reasons, pregnant women in many parts of West Africa including Nigeria frequently consume kaolin. This study was carried out to determine the influence of kaolin consumption on serum electrolytes, glucose and amylase levels of pregnant women attending antenatal clinic in a Teaching Hospital in the south east Nigeria. Methods: A total of eighty pregnant women recruited for this study were grouped as follows; Group 1, (30 geophagic pregnant women in the first trimester), Group 2 (30 geophagic pregnant women in the second trimester) and Group 3 (20 non-geophagic pregnant women that served as control). Subjects in Groups 1 and 2 were subdivided into three based on the quantity of kaolin consumed per week: group A (100 g/week), group B (150 g/week) and group C (200 $\mathrm{g} /$ week). Preliminary analysis of the calcium content of kaolin was carried out. Serum levels of potassium, sodium, chloride, bicarbonate, glucose and amylase of the subjects were determined. Results: Calcium level in kaolin was below the recommended daily intake in food. The concentrations of potassium in geophagic pregnant women who consumed $150 \mathrm{~g}$ and $200 \mathrm{~g}$ of kaolin per week were significantly $(\mathrm{p}<0.05)$ lower in both $1^{\text {st }}$ and $2^{\text {nd }}$ trimester groups., There was a significant $(\mathrm{p}<0.05)$ decrease in sodium concentration $(132.2 \pm 2.0)$ of the $2^{\text {nd }}$ trimester pregnant women that consumed $200 \mathrm{~g}$ of kaolin per week. The concentrations of chloride and bicarbonate were not significantly $(p>0.05)$ affected in all the groups. Serum amylase concentration decreased significantly $(\mathrm{p}<0.05)$ in the $1^{\text {st }}$ and $2^{\text {nd }}$ trimester pregnant women on $150 \mathrm{~g}$ and $200 \mathrm{~g}$ of kaolin per week, while the plasma glucose concentration was significantly $(\mathrm{p}<0.05)$ elevated in the same groups. Conclusion: This study concludes that kaolin consumption in pregnant women may predispose to gestational diabetes, electrolytes imbalance and reduced intes-
\end{abstract}


tinal enzymes activities.

\section{Keywords}

Geophargy, Kaolin, Pregnancy, Serum Electrolyte, Glucose, Amylase

\section{Introduction}

Eating of soil has been internationally practised throughout the world, in all age groups, races, and socio-economic environment [1]. The eating of clay (kaolin) occurs among cultural groups in many continents. Clay eating is widespread among women in Africa but in particular five African countries of Malawi, Zambia, Zimbabwe, Swaziland and South Africa, where an estimated prevalence level in the rural areas of these countries is put at $90 \%$ [2]. In human, it is postulated that kaolin consumption creates iron, zinc, or potassium deficiencies [3]. Kaolin ingestion is thought to inhibit absorption of iron from foods. Those who eat clay at the expense of healthier foods often develop malnutrition. This phenomenon of nutrient deficiency is exacerbated when clays with high cation-exchange capacities are ingested. Complications from geophagia include hypokalemia, hypogonadism, and iron deficiency [4]. In sub-Saharan Africa, the rate of geophagia among pregnant women ranges from $28 \%$ in Tanzania to $65 \%$ in Kenya [5], Geophagia has also been reported in Senegal, Mali [6], Guinea [7] as well as Nigeria [8]. Kaolin consumption (geophagia) is common among pregnant women, perhaps because of its anti-nausea effect [9]. A cross-sectional study showed that $46.4 \%$ of pregnant women in Southern Ebonyi State, Nigeria who were in attendance at antenatal clinics deliberately and regularly indulged in the habit of earth consumption [10]. Clay eating is observed among pregnant women in South Africa where the prevalence of pica among urban and rural black South African women was reported to be high [2]. There are reports that geophagia is common among the Tanzanians and Kenyans in the Eastern part of Africa, and that the prevalence remained high during pregnancy, and then declined after post-partum [11].

There is a hypothesis that geophagy is a physiological response to nutrients deficiencies, such as iron and calcium [12]. Pregnancy is a period of both increased nutritional needs and increased vulnerability Nutrition during pregnancy is increasingly demanding, especially regarding minerals such as iron and calcium, to support both the growing fetus and elevated blood production. Unfortunately, this period of nutritional need often occurs coincidentally with digestive difficulties such as nausea and vomiting. This, often enhances the eating of kaolin at first and second trimesters as anti-nausea agent [1]. Since kaolin consumption occurs during pregnancy, there is a likelihood of deleterious effects on both the mother and unborn child [13]. Kaolin has been noted to have adsorbing effect on other elements; thus chronic exposure may result in nutritional and electrolytes deficiency or even affect carbohydrate metabolism and intestinal 
enzyme activities, such as amylase. These likely biological consequences of kaolin consumption prompted this study in geophargic pregnant women.

\section{Materials and Methods}

\subsection{Materials}

Kaolin obtained from the main market in Awka metropolis, Anambra State, Nigeria. Acid mixture (Altran Chemicals, Enugu, Nigeria), FS240AA Atomic Absorption Spectroscopy (Agilent Technologies South San Francisco, USA), Ion selective Electrolyte (ISE) Analyser (Audicom AC 9900, Audicom Medical Instruments Co., Ltd., China). One Touch Ultramini Glucometer (LifeScan GmbH Switzerland), Teco Reagent Kit (Teco Diagnostic, Anaheim, USA). Benchtop centrifuge (Thomas Scientific, NJ, USA).

\subsection{Methods}

\subsubsection{Estimation of Calcium Content in Kaolin}

Five gram $(5 \mathrm{~g})$ of the dried kaolin was placed into a digestion flask and $20 \mathrm{ml}$ of acid mixture (650 ml conc $\mathrm{HNO}_{3} ; 80 \mathrm{ml}$ perchloric acid; $20 \mathrm{ml}$ conc $\mathrm{H}_{2} \mathrm{SO}_{4}$ ) was added. The flask was then, heated until a clear digest was obtained. The digest was diluted with distilled water to $100 \mathrm{ml}$ mark. The calcium content was measured using FS240AA Atomic Absorption Spectroscopy (Agilent Technologies South San Francisco, USA).

\subsubsection{Experimental Protocols}

This is a cross-sectional study involving eighty (80) pregnant women recruited from the antenatal clinic of Chukwuemeka Odimegwu Ojukwu University Teaching Hospital (COOUTH), Awka, Anambra State, Nigeria. They were pregnant women within first and second trimester of pregranacy. Ethical approval for the study was obtained from the Ethical Committee of the COOUTH (COOUTH/CMAC/ETH.C/VOL.1/01Q4 Date: 15/10/2018) before the commencement of the study, and written informed consent was obtained from each of the participants.

The subjects were divided into three main groups as follows: Groups 1 (30 geophagic pregnant women in the first trimester), group 2 (30 geophagic pregnant women in the second trimester) and group 3 (20 non-geophagic pregnant women that served as control). Groups 1 and 2 were subdivided into three (A C) each $(n=10)$ according to the quantity of kaolin consumed. The groups were treated as follows: Group A (14.3 g of kaolin/day), group B (21.4 g of kaolin/day) and group C (28.6 g of kaolin/day), corresponding to 100, 150 and $200 \mathrm{~g}$ of kaolin/week respectively.

\subsubsection{Estimation of Biochemical Parameters}

Blood samples were collected from the subjects via venipuncture and dispensed into plain test tubes. The samples were allowed to clot, suspended and then centrifuged at $2500 \mathrm{~g}$ for 10 minutes. The serum was separated from the cells and was kept in the freezer till ready for use. 
The following electrolytes: potassium, sodium, chloride and bicarbonate were analyzed using an automated Ion Selective Electrolyte (ISE) analyser (Audicom AC 9900, Audicom Medical Instruments Co., Ltd., China).

The blood samples were analyzed for random plasma glucose using One Touch Ultramini Glucometer (LifeScan GmbH Switzerland). Serum amylase level was determined by spectrophotometric method using Teco Reagent Kit (Teco Diagnostic, Anaheim, USA). The working reagent was prepared as specified. Amylase reagent $(1 \mathrm{ml})$ was introduced into test tubes and incubated at $37^{\circ} \mathrm{C}$ for 3 minutes. Thereafter, $25 \mu \mathrm{l}$ of samples and standards were added to the respective tubes and their absorbance read at $500 \mathrm{~nm}$ after $15 \mathrm{sec}$ and after 30 sec. for $2 \mathrm{~min}$. The amylase concentration was calculated using the formula:

Amylase concentration $=\left(\mathrm{Abs}_{\text {sample }} / \mathrm{Abs}_{\text {standard }}\right) \times$ standard concentration

\subsubsection{Data Analysis}

The results were expressed as the mean \pm standard deviation (SD). Data were analysed using SPSS and excel. The mean comparison was performed between groups using the one way ANOVA at 95\% confidence level.

\section{Results}

The calcium content of kaolin was $10.6 \mathrm{mg} / \mathrm{g}$ while the estimated daily calcium intake by the three groups of pregnant women on kaolin was 151.6, 226.8 and $303.2 \mathrm{mg}$ for 100, 150 and $200 \mathrm{~g}$ kaolin per week respectively. These values are below the recommended daily calcium intake of $1000 \mathrm{mg}$ per day.

\subsection{Effect of Kaolin Consumption on Serum Electrolytes in the $1^{\text {st }}$ Trimester Pregnant Women}

The mean serum concentration of potassium decreased significantly $(\mathrm{p}<0.05)$ in groups B and C that consumed $150 \mathrm{~g}$ and $200 \mathrm{~g}$ of kaolin per week compared to the control. The mean concentrations of sodium, chloride and bicarbonates were not significant $(\mathrm{p}>0.05)$ affected in all the groups (Table 1).

\subsection{Effect of Kaolin Consumption on Plasma Glucose and Amylase in $1^{\text {st }}$ Trimester Pregnant Women}

There was a steady increase in plasma glucose level of geophagic pregnant women in all the groups. This increase was significant $(\mathrm{p}<0.05)$ in groups B and $\mathrm{C}$ when compared to the control (Figure 1). The amylase concentration decreased significantly $(\mathrm{p}<0.05)$ in all the groups (Figure 1$)$.

\subsection{Effect of Kaolin Consumption on Serum Electrolytes in $2^{\text {nd }}$ Trimester Pregnant Women}

The mean serum potassium concentration in the $2^{\text {nd }}$ trimester pregnancy was significantly $(\mathrm{p}<0.05)$ reduced in groups $\mathrm{B}$ and $\mathrm{C}($ Table 2$)$. The serum sodium level decreased significantly $(\mathrm{p}<0.05)$ in group $C$. The serum concentrations of chloride and bicarbonate were not significantly $(p>0.05)$ affected in all the groups. 


\subsection{Effect of Kaolin Consumption on Plasma Glucose and Amylase in $2^{\text {nd }}$ Trimester Pregnant Women}

There was progressive increase in plasma glucose levels of kaolin consuming pregnant women. The increase was significant $(\mathrm{p}<0.05)$ in groups $\mathrm{B}$ and $\mathrm{C}$ when compared to the control (Figure 2). Amylase concentration was significantly lower in all the groups compared to the control.

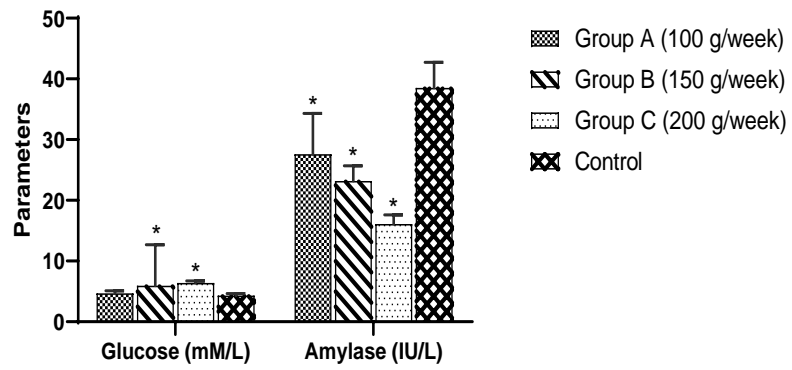

Figure 1. The effect of kaolin on serum glucose and amylase levels in 1 st trimester pregnant women, ${ }^{*} \mathrm{p}<0.05$.

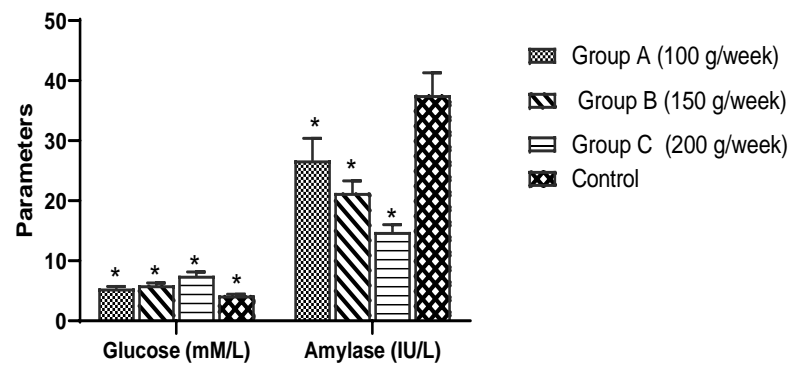

Figure 2. The effect of kaolin on serum glucose and amylase of $2^{\text {nd }}$ trimester pregnant women, ${ }^{*} \mathrm{p}<0.05$.

Table 1. The effect of kaolin on serum electrolytes in $1^{\text {st }}$ trimester pregnant women.

\begin{tabular}{ccccc}
\hline $\begin{array}{c}\text { Parameters } \\
(\mathrm{mEq} / \mathrm{L})\end{array}$ & $\begin{array}{c}\text { Group A } \\
(100 \mathrm{~g} / \text { week })\end{array}$ & $\begin{array}{c}\text { Group B } \\
(\mathbf{1 5 0} \mathrm{g} / \text { week })\end{array}$ & $\begin{array}{c}\text { Group C } \\
(\mathbf{2 0 0} \mathrm{g} / \text { week })\end{array}$ & Control \\
\hline $\mathrm{K}$ & $3.83 \pm 0.19$ & $3.41 \pm 0.17^{*}$ & $3.35 \pm 0.18^{*}$ & $4.32 \pm 0.19$ \\
$\mathrm{Na}$ & $133.61 \pm 1.30$ & $140.44 \pm 2.52$ & $137.63 \pm 1.82$ & $139.81 \pm 2.62$ \\
$\mathrm{Cl}$ & $96.81 \pm 2.50$ & $98.63 \pm 1.44$ & $96.40 \pm 1.02$ & $101.12 \pm 1.32$ \\
$\mathrm{HCO}_{3}$ & $25.62 \pm 1.51$ & $24.53 \pm 0.85$ & $25.70 \pm 1.14$ & $27.23 \pm 0.82$
\end{tabular}

${ }^{*} \mathrm{p}<0.05$.

Table 2. The effects of kaolin on serum electrolytes level of $2^{\text {nd }}$ semester pregnant women.

\begin{tabular}{ccccc}
\hline $\begin{array}{c}\text { Parameters } \\
(\mathrm{mEq} / \mathrm{L})\end{array}$ & $\begin{array}{c}\text { Group A } \\
(100 \mathrm{~g} / \text { week })\end{array}$ & $\begin{array}{c}\text { Group B } \\
(\mathbf{1 5 0} \mathrm{g} / \text { week })\end{array}$ & $\begin{array}{c}\text { Group C } \\
(\mathbf{2 0 0} \mathrm{g} / \text { week })\end{array}$ & Control \\
\hline $\mathrm{K}$ & $3.73 \pm 0.11$ & $3.52 \pm 0.14^{\star}$ & $3.26 \pm 0.25^{\star}$ & $4.22 \pm 0.21$ \\
$\mathrm{Na}$ & $135.12 \pm 1.84$ & $136.60 \pm 2.25$ & $132.25 \pm 2.11^{*}$ & $140.26 \pm 2.10$ \\
$\mathrm{Cl}$ & $97.70 \pm 1.36$ & $99.17 \pm 1.03$ & $97.01 \pm 1.47$ & $99.81 \pm 5.12$ \\
$\mathrm{HCO}_{3}$ & $26.64 \pm 0.84$ & $28.84 \pm 0.87$ & $25.28 \pm 0.37$ & $25.52 \pm 0.62$ \\
\hline
\end{tabular}

${ }^{*} \mathrm{p}<0.05$. 


\section{Discussion}

Our findings revealed that potassium level in kaolin consuming pregnant women significantly decreased in both $1^{\text {st }}$ and $2^{\text {nd }}$ trimester in a concentration dependent manner. A few studies have made similar observations [14] [15]. The low serum potassium in maternal blood could be attributed to cation binding activities of kaolin in the gastrointestinal tract [16]. This would reduce intestinal absorption and increased gastrointestinal loss of potassium. Hypokalaemia is a very dangerous situation in pregnancy as it can adversely affect both the mother and foetus. Hypokalaemia in pregnancy causes extreme muscle weakness and temporary paralysis of the arms and legs.

The reduced serum sodium level was noticeable in $2^{\text {nd }}$ trimester and at high kaolin concentration. This agreed with the report of Deloris et al. [17]. Low sodium concentration in $2^{\text {nd }}$ trimester may be as a result of increased plasma volume [18] [19]. The effect of kaolin consumption on plasma glucose was dependent on the quantity of kaolin consumed. The effect of unregulated and continuous kaolin consumption in pregnancy may manifest as gestational diabetes and its associated complications. The mechanism by which kaolin elevates plasma glucose is not known, however, previous findings revealed that some heavy metals were elevated in pregnant women on kaolin [20]. Heavy metals especially lead and arsenic had demonstrated inhibitory activities on insulin and were capable of inactivating over 200 enzymes [21]. It has been postulated that arsenite from kaolin has high affinity for sulphydryl group of insulin which can form a covalent bond with disulfide bridges in insulin receptors, thereby altering glucose metabolism [22]. An increased glucose level in maternal blood predisposes foetus to excessive birth weight, early (pretem) birth, respiratory distress syndrome, low blood sugar after birth, while the mother may exhibit high blood glucose and pre-eclampsia [23].

The low serum amylase level may be connected with kaolin adsorption of biomolecules. Studies have shown that kaolin can adsorb some substances [16] [24] [25] and may likely bind and inactivate intestinal enzymes. Though, clinical relevance of low serum amylase is poorly understood, animal and cellular studies regarding the relationship with endocrine and exocrine pancreas have shown that insulin secretion affected the basal and stimulatory amylase secretion via islet of acinar axis, and there was negative association between serum amylase and heavy metals [26]. High concentration of some heavy metals in geophargic pregnant women has been documented [20], and in biological systems heavy metals have been reported to inactivate enzymes, and affect cellular organelles and components [27].

\section{Conclusion}

There are significant reductions in the serum potassium, sodium and amylase levels, and increased plasma glucose level in geophargic pregnant level. There may be likelihood of gestational diabetes, electrolyte imbalance and low intesti- 
nal enzyme activity in geophargic pregnant women. Uncontrolled and unregulated consumption of kaolin by pregnant women as practised in many rural African communities may adversely impact on the outcome of pregnancy.

\section{Acknowledgements}

The authors wish to acknowledge the Antenatal Clinic, Chukwuemeka Odimegwu Ojukwu University Teaching Hospital (COOUTH), Awka, Anambra State, Nigeria for the permission to perform this study in the hospital.

\section{Authors' Contributions}

Experiments were designed by PAA and MNO, and carried out by TOZ. Execution of the study was supervised by PAA and MNO. All the authors participated in the manuscript preparation which was directed by PAA. The final manuscript was approved by all the authors.

\section{Conflicts of Interest}

The authors declare no conflicting interest.

\section{References}

[1] Sackey, D.S., Larbie, C. and Mensah, F.O. (2018) Geophagia, Nutrition and Health of Women with Pregnancy-Induced Hypertension. African Health Science, 18, 1243-1254. https://doi.org/10.4314/ahs.v18i4.46

[2] Walker, A.R.P., Walker, B.F., Sookaria, F.I. and Canan, R.J. (2017) Pica. Journal of Royal Social Health, 1147, 280-284.

[3] Sayers, G., Lipschitz, D.A., Sayers, M., Seftel, H.C., Bothwell, T.H. and Charlton, R.W. (2014) Relationship between Pica and Iron Nutrition in Johannesburg Black Adults. South Africa Medical Journal, 68, 1655-1660.

[4] Halstead, J.A. (1998) Geophagia in Man: Its Nature and Nutritional Effects. American Journal of Clinical Nutrition, 21, 1384-1393. https://doi.org/10.1093/ajcn/21.12.1384

[5] Thomson, J. (2007) Anaemia in Pregnant Women in Eastern Caprivi, Namibia. South African Medical Journal, 87, 1544-1547.

[6] Medilink (2004) Senegal: Clay as Delicacy and Danger. http://ipsnews.net/africa

[7] Glickman, L.T., Camara, A.O. and McCabe, G.P. (1999) Nematode Intestinal Parasites of Children in Rural Guinea, Africa: Prevalence and Relationship to Geophagia. International Journal of Epidemiology, 28, 169-174. https://doi.org/10.1093/ije/28.1.169

[8] Ademuwagun, Z.A., Ayoade, J.A., Harrison, I.E. and Warren, D.M. (1979) The African Therapeutic Systems. Crossroads Press (African Studies Association), Brandeis University, Waltham, 273.

[9] Vermeer, D.E. and Frate, D.A. (2009) Geophagia in Rural Mississippi: Environmental and Cultural Contexts and Nutritional Implications. American Journal of Clinical Nutrition, 32, 2129-2135. https://doi.org/10.1093/ajcn/32.10.2129

[10] Njoku, I., Nnenna, I., Obinna, I., Felicia, E., Ngozi, E., Gregory, O., Florence, I., Uwakwe, O. and Joseph, E. (2017) Geophagy as Risk Behaviour for Gastrointestinal 
Nematode Infections among Pregnant Women Attending Antenatal Clinics in a Humid Tropical Zone of Nigeria. African Health Science, 17, 24-31. https://doi.org/10.4314/ahs.v17i1.5

[11] Young, S.L., Goodman, D., Farag, T.H., Ali, S.M., Khatib, M.R., Khalfan, S.S., Tielsch, J.M. and Stoltzfus, R.J. (2007) Geophagia Is Not Associated with Trichuris or Hookworm Transmission in Zanzibar, Tanzania. Royal Society of Tropical Medicine and Hygiene, 101, 766-772. https://doi.org/10.1016/j.trstmh.2007.04.016

[12] Abrahams, P.W. (1997) Geophagy (Soil Consumption) and Iron Supplementation in Uganda. Tropical Medicine of International Health, 2, 617-623. https://doi.org/10.1046/j.1365-3156.1997.d01-348.x

[13] Grigsby, R.K. (2013) Clay Eating. New Georgia Encyclopedia.

[14] Barragry, J.M. and Morris, D.V. (1980) Fatal Dependence on Kaolin and Morphine Mixture. Postgraduate Medical Journal, 56, 180-181. https://doi.org/10.1136/pgmj.56.653.180

[15] Anjum, K.S. and Alka, N.S. (2013) Electrolyte Status in Preeclampsia. International Interdisciplinary Research Journal, 3, 30-36.

[16] Kraepiel, A.M., Keller, K. and Morel F.M.M. (1999) On the Acid Base Chemistry of Permanently Charged Minerals. Journal of Environmental Science Technology, 32, 2829-2838. https://doi.org/10.1021/es9820184

[17] Deloris, A., Richardson, D., Odom, L., Cromwell, K., Grant, D., Myers, M., Cadet, E., Mahama, H., Rangari, V., Pace, R., Ankumah, R., Kpomblekou, A.K. and Fluker, C. (2015) The Biological Consequences of Kaolin Geophagia. Professional Agricultural Workers Journal, 2, 2-3.

[18] Blaustein, M.P., Zhang, J., Chen, L. and Hamilton, B.P. (2006) How Does Salt Retention Raise Blood Pressure? American Journal of Physiology Regulation and Integral Compound Physiology, 290, 514-523. https://doi.org/10.1152/ajpregu.00819.2005

[19] Indumati, V., Kodliwadmath, M.V. and Sheela, M.K. (2011) Role of Serum Electrolytes in Pregnancy Induced Hypertension. Journal of Clinical and Diagnostic Research, 5, 66-69.

[20] Akah, P.A., Zeigbo, T.O., Ofokansi, M.N. and Onyeto, C.A. (2020) Effect of Kaolin Consumption on Serum Heavy Metal Levels of Pregnant Women. International Journal of Sciences, 9, 28-32.

[21] Hughes, M.F. (2016) Arsenic Toxicity and Potential Mechanisms of Action. Toxicology Letter, 133, 1-16. https://doi.org/10.1016/S0378-4274(02)00084-X

[22] Mouse Phenome Database (2002) 129S6/Sv. http://www.jax.org

[23] Mayo Clinic (2018) Guild to Healthy Pregnancy. Hapercollins Publishers Inc., New York.

[24] Gamiz, E., Caballero, E., Rodriguez, M.D. and Delgado, C.F.R. (1998) Characterization of Spanish Kaolins for Pharmaceutical Use. I. Chemical and Mineralogical Composition, Physico-Chemical Properties. Bollettino Chimico Farmaceutico, 127, 114-121.

[25] Babich, H. and Stotzky, G. (2017) Reductions in Toxicity of Cadmium to Microorganisms by Clay Minerals. Applied Environmental Microbiology, 3, 696-705. https://doi.org/10.1128/AEM.33.3.696-705.1977

[26] Yilmaz, U.E., Yilmaz, N., Titiz, I., Basaranoglu, M. and Tarcin, O. (2012) The Utility of Amylase and Lipase as Reliable Predictive Markers for Functioning Renal Graft. Annals of Transplantation, 17, 77-84. https://doi.org/10.12659/AOT.883461 
[27] Wang, S. and Shi, X. (2001) Molecular Mechanisms of Metal Toxicity and Carcinogenesis. Molecular and Cell Biochemistry, 222, 3-9.

https://doi.org/10.1007/978-1-4615-0793-2_1 